\title{
PUBLIC GOODS VERSUS THE FARM PRICE-COST SQUEEZE: SHAPING THE SUSTAINABILITY OF THE EU'S COMMON AGRICULTURAL POLICY
}

\author{
Bazyli CZYŻEWSKI ${ }^{*}$, Anna MATUSZCZAK², Radosław MIŚKIEWICZ ${ }^{3}$ \\ ${ }^{1,2}$ Faculty of Economics, Poznan University of Economics and Business, \\ al. Niepodległości 10, 61-875 Poznań, Poland \\ ${ }^{3}$ Faculty of Organization and Management, Silesian University of Technology, \\ ul. Roosevelta 26, 41-800 Zabrze, Poland
}

Received 23 March 2018; accepted 25 November 2018

\begin{abstract}
There is a consensus that farmers are subject to farm price-cost squeeze (PCS) when commodity prices fall and costs of production rise long-term. Willard Cochrane was the first to examine this phenomenon, introducing the notion that farmers are on a market treadmill. PCS is still a principle economic problem in agriculture touching farms in all over the world. It results from flexible prices but also from monopsony structures where recipients of commodities seize the opportunity of suboptimal pricing. Many studies indicate increasing retail farm price spreads but this lacks empirical studies on the effects of different types of subsidies on PCS. This work attempted to model EU Common Agricultural Policy (CAP) impact on PCS using the Constant Elasticity of Substitution (CES) production function, specified as in most CGE models. However, the authors tested the assumption of flexible prices reacting to changes in productivity. This approach is novel, while supported with an input-output analysis used to precisely decompose price and volume (productivity) effects at the level of a FADN representative farm. The results help to shape CAP shedding light on the present treadmill mechanism and showing that provision of public goods may be a remedy for market imperfections, whereas decoupled payments have the opposite influence.
\end{abstract}

Keywords: sustainable development, environmental public goods, agricultural policy, CES function, productivity

JEL Classification: Q11, Q12, Q18.

\section{Introduction}

When farm commodity prices fall and costs of production rise, farmers can get caught in a "farm price-cost squeeze". Willard Cochrane was first to examine this phenomenon, introducing the notion that farmers are on a "market treadmill" which, despite their constant efforts to improve productivity, wears away any profits that might result (Cochrane, 1958;

*Corresponding author. E-mail: bazyli.czyzewski@ue.poznan.pl

This is an Open Access article distributed under the terms of the Creative Commons Attribution License (http://creativecommons. org/licenses/by/4.0/), which permits unrestricted use, distribution, and reproduction in any medium, provided the original author and source are credited. 
Hayami \& Herdt, 1977; Levins \& Cochrane 1996). The essence of the price-cost squeeze (PCS) is, therefore, that agricultural income does not grow in line with increases in productivity. The most basic way to measure PCS on a farm is to directly compare the prices received by farmers with the prices they pay for inputs, in the form of price ratios (Shields, 2010; Chen \& Lent, 1992). In the last decade, PCS was most evident in the livestock sector, particularly dairy, considering its global markets (Freebairn, 2017) but also concerned land market. According to Ciaian, Kancs, and Espinosa (2017), on average, 27\% of decoupled payments after the last reform of CAP in 2013 are channelled to non-farming landowners in the EU increasing renal fees for farmers. Although there is a consensus that agricultural markets are subject to PCS long-term, one can also find contradictory findings based on price co-integration analyses (Campiche, Bryan, Richardson, \& Outlaw, 2006; Moss, 1992) The influence of agricultural policy on mitigating PCS is the most debatable part of this theory (Rizov, Pokrivcak, \& Ciaian, 2013). Therefore there is a lack of empirical studies on the effects of different types of subsidies on PCS because the mainstream dispute has focused on the question of how a monopsony or flexible prices impact farm PCS (Millard \& O'Grady, 2012; Chen \& Lent, 1992). The authors take an attempt to fill this gap through modelling CAP variables affecting PCS according to the Constant Elasticity of Substitution (CES) production function using a specification in line with the production technology modelled in most CGE models. The research tests two hypotheses $1 /$ agricultural prices are flexible, in the meaning that they react to the changes in productivity, as the treadmill theory assumed 2/ CAP direct payments stimulate PCS, while payments for public goods and investment subsidies have the opposite effect being a remedy for PCS. The second statement seems to be a challenge since in the literature it has usually been advocated that ecological incentives do not coincide with a higher productivity (Majiwa, Leeb, \& Wilsonb, 2018) or might perform better under regionspecific budgeting (Kiryluk-Dryjska \& Beba, 2018). Although European farmers are the most important stakeholders of the formulated problems, testing the second hypothesis is a matter of social wellbeing since providing public goods contributes to the sustainable development. Those solutions which improve a market mechanism and promote ecological attitudes at the same time are the most desirable for policymakers (Chodakowska \& Nazarko, 2017).

The paper is organized into the following parts: Review of state-of-art, considering main literature strands (treadmill theory, monopsony power, and capital productivity), Methodology, Results and problem solution, Conclusions.

\section{Review of state-of-art}

\section{Prices-cost squeeze in the treadmill theory}

The idea of the agricultural treadmill is quite simple but powerful. In an economy where technological advance reduces the per unit costs of production, producers who adopt a new technology early on realise increased net returns, because the new technique reduces their costs while aggregate supply is not increased sufficiently to lower prices (Gabre-Madhin, Barrett, \& Dorosh, 2002; Czyżewski \& Majchrzak, 2018). As the first adopters accumulate income gains, other farmers adopt the technology until its widespread usage results in a 
shift in the aggregate supply and a lower commodity price. Hence, early adopters benefit, at least temporarily, while late adopters and non-adopters never benefit. However, Dürr (2016) proved the opposite showing that smallholder production multipliers are as strong as those of large farmers' and even stronger, but this is a very sparse opinion. We recall that demand is highly inelastic, and in the case of increasing supply, a disproportionately high decrease in prices can be observed, and ultimately, it turns out to be disadvantageous for revenue. In a very recent study of Barath and Ferto (2017) an increasing trend in total factor productivity TFP of European farms, especially in the New Members States has been proved, with technological change being the predominant contributing, while real farm incomes remained stable or even declining. The underlying phenomenon is called the King effect and is well-described in the literature (Heberton Evans Jr., 1967; Tweeten \& Zulauf, 2008; Chen, Huffman, \& Rozelle, 2011). Historically, measures of the elasticity of demand in industrialised countries are around -0.2 and in developing countries around -0.3 . The effect of inelastic price demand is compounded at the producer level by the wedge between retail and producer prices. Thus, with an elasticity of -0.2 , retail prices must fall by 10 percent to increase consumption by 2 percent, but if 60 percent of each consumer dollar is absorbed by the marketing system, farm prices would then fall by around 25 percent (Cochrane, 1958; Gabre-Madhin, Barrett, \& Dorosh, 2002). It can be said that commodity prices at farm level are very flexible (Tomek \& Robinson, 1981), in other words a price elasticity of demand is low. However, it would be an unjustified simplification to say that price flexibility is the only reason for the treadmill. The reality is more complex. There are three strands of approaches to this problem: demand-oriented (presented above), supply-oriented, and behavioural. In the supply-oriented reasoning, the relative deprivation of farmers' incomes is advocated by a specificity of agricultural production (Heinrichsmayer \& Witzke, 1991; Gardner, 1992), which implies a low mobility of labour and a reverse supply curve, described by Czajanow (1931, 1966, 1991). Farmers invest in conditions where the expected return on investment is higher than the cost of implementation. Conversely, the situation discouraging investment takes place if the expected income is lower than the resale value of the purchased assets. However, if the expected revenue is lower than the cost of acquisition but higher than the resale value, capital becomes completely immobile and is "locked" into agriculture, called the "high-profit trap". (Johnson, 2000). The high-profit trap is closely linked to the problem of opportunity costs for labour in agriculture because, if capital is trapped, mobility of labour also decreases. On the other hand, this situation leads to land-use conflicts (Milczarek-Andrzejewska, Milczarek-Andrzejewska, Zawalińska, \& Czarnecki, 2018). Usually, agricultural work is not remunerated at the level of alternative income in other industries. As some economists point out, the reason for this is the peculiarity of farmers' qualifications. On the other hand, the behavioural approach focuses on the question of why maximising productivity in agriculture produces worse results than in other sectors of the economy. In older works, attention was paid to the fact that farmers maximise revenues (sales) rather than the marginal productivity of employed factors. Further studies have questioned this approach by attaching greater importance to the limited adaptability of farmers to a changing market (Vergopoulos, 1978) or to delayed responses to these changes (Boháčková, 2014). 


\section{Squeezing prices by a monopsony power}

In monopsony market structures, recipients of commodities seize the opportunity of flexible prices (Chen \& Lent, 1992). There is growing concern about the use of market power by supermarkets all over the world (Galbraith, 1993). Farmers receive a shrinking share of the retail food dollar, and the portion they receive will not sustain them. USDA data indicates rapidly increasing farm to retail price spreads along with deteriorating farm value for a fixed market basket of goods for at-home consumption (Shields, 2010; Pawlak, 2018). However, even with supermarket monopsony pricing, the farm sector receives enough to cover outlays on variable inputs, and so is willing to supply the quantity sought by the monopsony supermarket. However, producer surplus, or rent received for land and other fixed inputs is reduced. Because land is fixed in supply, with no alternative use, as long as the rent and asset value exceeds zero, it will continue in food production. At most, monopsony pricing can transfer some of the economic rent, or producer surplus, earned on favourably endowed, fixed supply agricultural land from farmers to the supermarkets, and then a one-off fall in land asset values (Freebairn, 2017). The supply curve is represented by the farm production marginal cost curve with a positive slope to reflect different endowment characteristics of the fixed supply of land. To maximise profits, a monopsony calculates the marginal factor cost of farm input purchases given by:

$$
M F C=d(M C Q) / d Q=M C(1+1 / E L S),
$$

where, $(M C Q)$ is input expenditure, $M C$ is marginal cost, or average price given by the competitive supply curve, and ELS is the elasticity of the supply curve for the farm product input. We recall that for non-farm inputs of labour the supermarket is also a price taker, so a monopsony price depends on the MFC and supply/marginal cost curve, c.f. Figure 1. From equation 1 it can be deduced that the lower elasticity of supply, the higher the MFC, and monopsony rent simultaneously rises. This conclusion may be very important if we assume that CAP direct payments decrease the elasticity of supply.

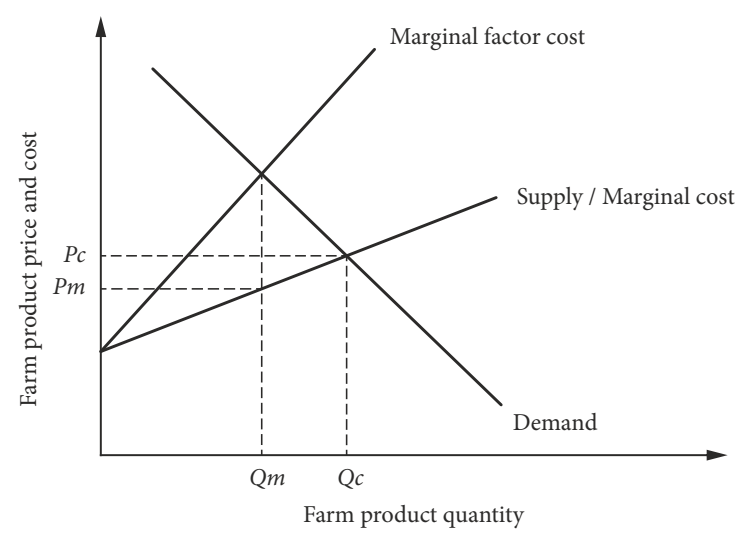

Figure 1. Monopsony price $(P m)$ at farm level vs competitive price $(P c)$ (source: own elaboration on the basis of Freebairn 2017) 


\section{Capital productivity versus Cochrane's treadmill}

As stated above, PCS mainly affects the laggards and farmers on the treadmill who are constantly under pressure to adopt new technologies. In this context, the relation of capital productivity and farmers' incomes is much more complex than it apparently seems, and may differ among different groups of farmers. To better understand the role of productivity in the treadmill theorem, we should look deeper into farmers' income function. GDP growth is measured more exponentially than linearly. The historical data, as well as The Organisation for Economic Co-operation and Development [OECD] long-term forecasts, proves that an exponential tendency dominates (OECD, 2017). The same goes for capital productivity, which can be explained by the nature of technological progress. GDP is a synonym of income - the main difference concerns taxes on products (VAT) which are not included in the latter. If capital productivity rises and simultaneously a resource of capital factor augments at the expense of labor and land, the income of the business increases exponentially. For this reason, the exponential form of farmers' income function is usually tested where capital productivity stands for an explanatory variable. If we consider the following function:

$$
Y=e^{\alpha X}
$$

where $Y$ stands for farmer income, $X$ for capital productivity, positive $\alpha$ is specific for the early adopters, while negative $\alpha$ concerns the laggards. Therefore, the question arises of whether positive $\alpha$ means PCS does not occur. It is worth noting that this function has interesting properties if transformed to growth rate form, as $(d Y / d X) / X$. We get the income growth rate function:

$$
y=\frac{e^{\alpha X}}{X} .
$$

The minimum points of these functions indicate the level of productivity at which, after being exceeded, the income growth rate becomes a positive productivity function. Below this threshold, productivity growth results in a gradually lower income growth rate $-c f$. Figure 2 .

We believe that this problem can be called "the growth rate treadmill", which is a new contribution to the subject literature. The growth rate treadmill affects mainly small and medium-sized farms (below the productivity threshold). They are condemned to a vicious circle, in which efforts to improve efficiency result in an increasingly lower income growth rate, while in the largest farms, these efforts bring an increasingly higher income growth rate. Moreover, the competitiveness gap between the strongest and the remaining farms grows. The mechanism described above hinders the income emancipation of small farms and favours large farms. To sum up, if the traditionally understood market treadmill has lost significance, the growth rate treadmill would still operate. This kind of treadmill means increasing relative deprivation of farmers income compared to overall economic growth, which has been shown to be exponential in the long-term. To sum up, capital productivity paradoxically plays a positive role in overcoming the treadmill and PCS, because it helps laggards first to catch up, and then to become early adopters. We can also derive a second useful clue for forward analysis that supply elasticity on farm level is an inhibitor of PCS caused by monopsony structures (the higher elasticity, the lower monopsony rent). These premises help to discuss 


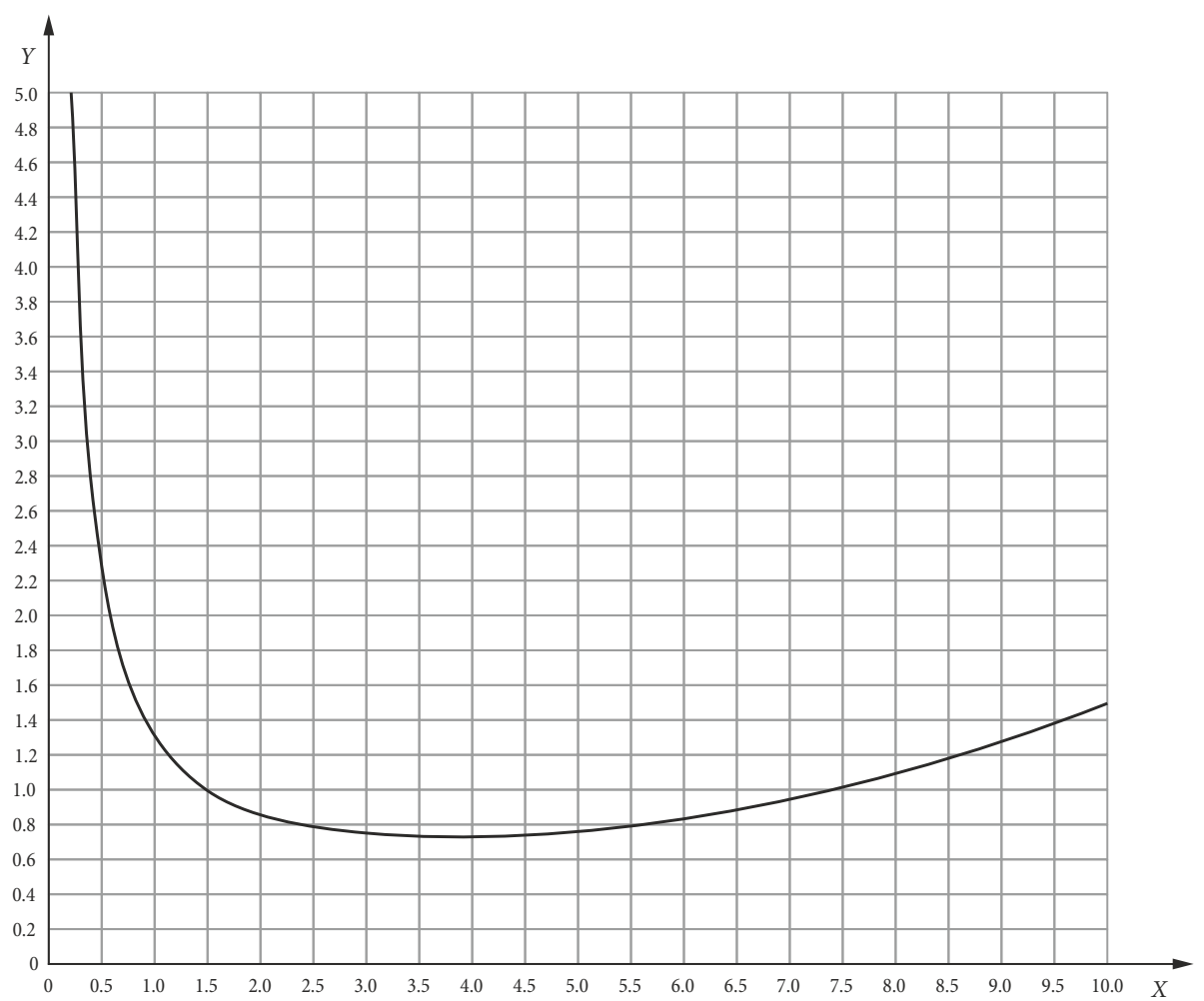

Figure 2. Farm income growth rate $(Y)$ as a function of technical productivity $(X)$ as in equation 3 (source: own calculations at the basis of EU-15 panel data from Eurostat)

the contribution of other authors to the issue of the policy drivers of PCS. Although it is difficult to find a similar approach to this problem as challenged in this article, there are many studies on the influence of CAP subsidies on productivity factors in agriculture. If we know the magnitude of capital productivity for the occurrence of PCS, we can also deduce the expected impact of a policy on this phenomenon. The most comprehensive review of studies on subsidies' effect on productivity can be found in the report by Dudu and Kristkova (2017). The majority of results show that the effect of CAP subsidies on productivity is negative, and improves after decoupling. We shall discuss the respective studies in the "results and discussion" section. The authors cited also formulated the general opinion, which is in line with our point of view, that in most of the studies, agricultural subsidies are treated ad-hoc and mostly as a uniform category. However when separating the individual subsidy groups, the productivity effects of subsidies might become positive.

Payments for public goods, investment subsidies and decoupled payments against the farm price-cost squeeze

In this part, we comment on the potential effect of different CAP payment groups on PCS. There are premises for the hypothesis that public goods (PGs) provision alleviates the market treadmill: 
- A higher share of payments for PGs in CAP subsidies may favour more sustainable development of farms, as it stimulates multifunctional activity and a diversification of incomes (Czyzewski, Guth, \& Matuszczak, 2018a; Czyżewski, Matuszczak, \& Muntean, 2018b; Staniszewski 2018). Thus, the compulsion to increase productivity loses its importance, since the growth rate of household incomes is maintained by off-farming activities;

- A higher share of payments for PGs enhances farm activities for which the price flexibility is lower, and the elasticity of demand is higher, e.g. organic food production or agritourism services;

- The supply of PGs is freed from the market treadmill, since it increases the elasticity of supply of agricultural commodities. Farms exclude less useful land from agricultural production, where capturing land rent is quite difficult in market conditions. In this way, the remaining land resource becomes more productive and better market-oriented (Dudu \& Kristkova, 2017).

PGs are less vulnerable to the rent leaks reported by many sources (OECD, 2000) because they are not capitalized in the lease fee due to the lack of market valuation mechanisms for PGs.

Similarly, investment subsidies (IS) should have similar mitigating effects on PCS as they also increase productivity and the chances of being early adopters of a new technology. They also increase the elasticity of supply and reduce the flexibility of agricultural prices at the farm level through countercyclical actions (e.g. development of storage facilities, shortening of marketing channels). When it comes to decoupled payments (DP), we expect that they will stimulate PCS and surplus leakage through agricultural prices. These payments weaken the links of producers to the market and reduce the elasticity of supply. They sustain an inefficient agrarian structure and do not create incentives for productivity growth, making it harder for a farm to reach the threshold of optimal productivity above which the market treadmill does not occur (see Figure 1).

\section{Methodology}

\section{Theoretical model}

We describe production technology using a Constant Elasticity of Substitution (CES) production function with constant returns to scale, and factor-specific technology parameters, as Dudu and Kristkova (2017) did. This specification (5) is in line with the production technology modelled in most CGE models:

$$
\begin{aligned}
& \operatorname{minCOST} T_{c, t}=P D_{C, T} D_{c, t}+P K_{c, t} K_{c, t}+P L_{c, t} L_{c, t} ; \\
& O U T_{c, t}=\left[\alpha_{D}\left(A_{D} D_{c, t}\right)^{\frac{\sigma-1}{\sigma}}+\alpha_{K}\left(A_{K} K_{c, t}\right)^{\frac{\sigma-1}{\sigma}}+\alpha_{L}\left(A_{L} L_{c, t}\right)^{\frac{\sigma-1}{\sigma}}\right]^{\frac{\sigma}{\sigma-1}},
\end{aligned}
$$

where COST is cost, OUT is output, $D$ is land, $K$ is capital stock, and $L$ is labour. $P D, P K$ and $P L$ stand for the prices of land, capital and labour, respectively. Further $\alpha D, \alpha K$ and $\alpha L$ are the distribution parameters in the CES function; $A D, A K$ and $A L$ are factor-augmenting 
technology parameters for land, capital and labour respectively. Lastly, is the elasticity of substitution between capital, land and labour.

Then, we solved the minimisation problem (4) for factors cost, which yielded factor demand equations expressed in growth rates:

$$
\begin{aligned}
& \left(d_{c, t}-\text { out }_{c, t}\right)=(\sigma-1) a_{D}+\sigma\left(\text { pout }_{c, t}-p d_{c, t}\right)=>\left(\text { pout }_{c, t}-p d_{c, t}\right)= \\
& \frac{(1-\sigma)}{\sigma} a_{D}-\frac{1}{\sigma}\left(\text { out }_{c, t}-d_{c, t}\right) ; \\
& \left(k_{c, t}-o u t_{c, t}\right)=(\sigma-1) a_{K}+\sigma\left(\text { pout }_{c, t}-p k_{c, t}\right)=>\left(\text { pout }_{c, t}-p k_{c, t}\right)= \\
& \frac{(1-\sigma)}{\sigma} a_{K}-\frac{1}{\sigma}\left(\text { out }_{c, t}-k_{c, t}\right) ; \\
& \left(l_{c, t}-\text { out }_{c, t}\right)=(\sigma-1) a_{L}+\sigma\left(\text { pout }_{c, t}-p l_{c, t}\right)=>\left(\text { pout }_{c, t}-p l_{c, t}\right)= \\
& \frac{(1-\sigma)}{\sigma} a_{L}-\frac{1}{\sigma}\left(\text { out }_{c, t}-l_{c, t}\right) .
\end{aligned}
$$

Further, we replaced endogenous (dependent) factor productivity from the left side of the equation with exogenous prices. Such an operation has also been possible to perform in CGE models, as GTAP (Hertel \& Tsigas, 1997; Hertel, Tsigas, \& Narayanan, 2008). In this way, we test the hypothesis that the price gap, among other things: $\left(p o u t_{c, t}-p d_{c, t}\right)$, is in a functional relationship with the productivity gap, i.a.: $\left(o u t_{c, t}-d_{c, t}\right)$. This means that prices are flexible, however, we do not claim the causality of productivity change on the price gap. We inquire to what extent a change in factor productivity can explain the price gap. Hence, the price gap, defined as in the equations $6-8$, stands for our dependent variable, while the productivity gap and also different groups of subsidies (public goods payments, decoupled and investment subsidies), as factors augmenting technology parameters, are the explanatory variables. It is assumed that factor-augmenting productivity parameters in the agricultural sector are explained by various productivity drivers. Considering that the subject of our interest is to quantify the impact of CAP subsidies on the flow of economic surplus by prices that cause PCS, $a F$ parameters are explicitly linked to shares of subsidies in agricultural output which cover more than $90 \%$ of total CAP subsidies:

$$
a F=a_{K, L, D}=\delta_{P G} \frac{P G_{c, t}}{O U T_{c, t}}+\delta_{I S} \frac{I S_{c, t}}{O U T_{c, t}}+\delta_{D P} \frac{D P_{c, t}}{O U T_{c, t}}+u_{c}+e_{c, t},
$$

where $P G, I S$ and $D P$ stands for public goods payments (defined in the previous part), investment subsidies and decoupled payments respectively (according to EU FADN typology), a time-invariant part of the unobserved heterogeneity of countries and means idiosyncratic disturbance for each observation.

\section{Proxies}

We calculated both the price gap and the productivity gap using an input-output approach (Hicks-Moorsteen TFP index, cf. Coelli, Prasada Rao, Donnell, \& Battese, 2005; Dürr 2016) with reference to the EU FADN input-output matrix for representative farms of different economic size (SO) ranges (27 EU countries, 2004-2012, 6 SO classes). We use the fol- 
lowing proxies (10-11) which make it possible to express PCS and the productivity gap in monetary units $(€) . \Delta P r_{c, t}$ and $\Delta I N r_{c, t}$ decomposes respectively the price change effect and volume change effect. The first reflects an outflow or inflow of a surplus through changes in prices (in $€$ ), the latter measures the change of total factor productivity in real terms, or in other words the change in real income also (in $€$ ):

$$
\begin{aligned}
& \left.\begin{array}{l}
\left(\text { pout }_{c, t}-p d_{c, t}\right) \\
\left(\text { pout }_{c, t}-p k_{c, t}\right) \\
\left(\text { pout }_{c, t}-p l_{c, t}\right)
\end{array}\right\}\left[\sum_{i=1}^{n}\left(\frac{Q_{i t} \cdot P_{i t}}{H I C P}-Q_{i t} \cdot P_{i t-1}\right)\right]-\left[\sum_{j=1}^{m}\left(\frac{F_{j t} \cdot R_{j t}}{H I C P}-F_{j t} \cdot R_{j t-1}\right)\right]=\Delta \operatorname{Pr}_{c, t} ; \\
& \left.\left.\begin{array}{l}
\left(\begin{array}{l}
\text { out } \left._{c, t}-d_{c, t}\right) \\
\left(\text { out }_{c, t}-k_{c, t}\right) \\
\left(\text { out }_{c, t}-l_{c, t}\right)
\end{array}\right\}
\end{array}\right\} \sum_{i=1}^{n} Q_{i t} \cdot P_{i t-1}-\sum_{i=1}^{n} Q_{i t-1} \cdot P_{i t-1}\right)-\left(\sum_{j=1}^{m} F_{j t} \cdot R_{j t-1}-\sum_{j=1}^{m} F_{j t-1} \cdot R_{j t-1}\right)=\Delta I N r_{c, t},
\end{aligned}
$$

where HICP stands for inflation rate, $Q i$ is quantity of product $i$ in subsequent years $(t-1, t)$, in $n$-elemental matrix of products (outputs), $F j$ is quantity of external input $j$ in subsequent years $(t-1, t)$, in $m$-elemental matrix of products (inputs), $P i$ stands for prices of product $i$ in subsequent years $(t-1, t)$, and $R j$ for prices of external input $j$ in subsequent years $(t-1, t)$

Our input-output matrix for the representative farms covers the EU FADN variables specified in Table 1. The respective price indices come from the EAA Eurostat database.

Table 1. Input-output codes for the representative farm in EU Farm Accountancy Data Network [EUFADN] (source: EU Farm Accountancy Data Network [EUFADN], (10.10.2017). http://ec.europa.eu/ agriculture/rica/database/database_en.cfm)

\begin{tabular}{|l|l|}
\hline$i-$ output $(€):$ & $\begin{array}{l}\text { SE140, SE146, SE145, SE150, SE155, SE160, SE165, SE170, SE175, SE180, SE185, } \\
\text { SE190, SE195, SE200, SE216, SE220, SE225, SE230, SE235, SE240, SE245, SE251, } \\
\text { SE256, SE 395 }\end{array}$ \\
\hline$j-$ input $(€):$ & $\begin{array}{l}\text { SE285, SE295, SE300, SE305, SE310, SE320, SE330, SE331, SE340, SE345, SE350, } \\
\text { SE356, SE360, SE370, SE375, SE380, SE390, SE408 }\end{array}$ \\
\hline
\end{tabular}

Regarding the definition of payment for PGs employed here, we are aware that the choice of CAP programmes fulfilling this criterion will be subjective. We have adopted the criterion that selected schemes are intended to generate a specific public amenities. Hence, environmental subsidies stimulate efforts to improve the rural landscape (ponds, trees, baulks), preserve the cultural values of rural areas, recover natural ecosystems of meadows, protect soils and waters, create buffer zones, preserve traditional orchards, etc. Subsidies to less-favoured areas (LFA) are primarily aimed at maintaining the vitality of rural areas, preserving landscape values, promoting environmentally friendly farming, and preventing depopulation. Setaside premiums aim to diversify crops and to preserve ecological areas, while other subsidies for rural development support afforestation, and ecological balance. Hence, there are clear links to public goods amenities in the case of the following schemes: agri-environmental subsidies (SE621), LFA (SE622), set-aside subsidies (SE612) and other rural development subsidies (SE623), according to the EU FADN typology. 


\section{Empirical model}

Finally, we estimate the following regression (9) separately for each of the 6 SO farm classes according to EUFADN:

$$
\frac{\left|\Delta P r_{c, t}\right|}{O U T_{c, t}}=\frac{(1-\sigma)}{\sigma}\left(\delta_{P G} \frac{P G_{c, t}}{O U T_{c, t}}+\delta_{I S} \frac{I S_{c, t}}{O U T_{c, t}}+\delta_{D P} \frac{D P_{c, t}}{O U T_{c, t}}+u_{c}\right)+\frac{1}{\sigma} \frac{\left|\Delta I N r_{c, t}\right|}{O U T}+e_{c, t} .
$$

We use absolute values for the price gap and also for the productivity gap that implies changes in the expected sign of the latter (from “-“ to “+”). Using absolute values of $\Delta \operatorname{Pr}_{c, t}$ and $\Delta I N r_{c, t}$ addresses all probable relationships of these variables. It is most likely that a productivity change is positive and rising while a price gap change is negative and declining $\left(\Delta I N r_{c, t} \uparrow\right.$ and $\left.-\Delta P r_{c, t} \downarrow\right)$ as well as the opposite circumstances. This may be derived from the treadmill theorem, but it has also been confirmed by the descriptive statistics in Table 2 and 3. Another situation, theoretically covered by absolute values, i.e. when $\Delta I N r_{c, t} \uparrow$ correlated with $\Delta P r_{c, t} \uparrow$ and the opposite $\left(-\Delta I N r_{c, t} \uparrow\right.$ and $\left.-\Delta P r_{c, t} \uparrow\right)$ is very unlikely, because farmers are not able to proportionally adjust production to the growth or drop of prices in the same period (a lag is inevitable). Furthermore, $\left|-\Delta P r_{c, t}\right|$ corresponds to the definition of PCS employed by Campiche et al. (2006) and Moss (1992) who assumed that PCS would occur if series of inputs and outputs prices were not cointegrated. If this is the case both variants are possible: the narrowing or widening price gap.

Our database allows us to employ one of the panel data methods. Although a prominent advantage of using panel data is that they contain information about the heterogeneity of the phenomenon in which we are interested, both in time and space, most panel data methods do not allow us to separately model the consequences of changes of that phenomenon over time or the effects of its heterogeneity in space. However, this analysis aims to analyse the impact of different types of support (variables that differ predominantly in space) and the influence on productivity change (a variable that significantly changes over time). Therefore, we have decided to employ the seminal within-between specification advocated by Bell and Jones (2015) and previously by Mundlak (1978), which can be written in the following general form:

$$
y_{c, t}=\propto+\beta\left(x_{c, t}-\bar{x}_{c}\right)+\gamma \bar{x}_{c}+\left(\varepsilon_{c}+e_{c, t}\right),
$$

where $x_{c, t}$ is a set of time-variant variables, $\bar{x}_{c}$ consists of $x_{c, t}$ means calculated for each country $\mathrm{j}$ (which by definition are time-invariant). The error term presented in brackets consists of two parts: a time-invariant element $\varepsilon_{c}$ that reflects the unobserved heterogeneity of countries and an idiosyncratic disturbance $e_{c, t}$ for each observation. The parameter $\beta$ reflects the within effect, while $\gamma$ captures the between effect which can be interpreted as the impact of a unitary difference in $x_{c, t}$ among EU-27 countries on the dependent variable.

\section{Robustness}

The within-between specification can be treated as a variant of a random effects model, but where explanatory variables are divided into their time and varying cross-country parts. The seminal within-between model makes it possible to solve the endogeneity problems found in RE modelling. According to Wooldrige (2013) and Schunck (2013), the RE model 
is consistent only if the within and between variances are equal. Otherwise, the estimation is biased, since the unaccounted variance will be absorbed by the unit-specific error and will be correlated with the independent variables, violating the assumptions of the RE model. This problem would be inevitable in our dataset, because it is very unlikely that a change in subsidies has the same effect on the price gap in different countries. The endogeneity problem has been successfully solved using the within-between approach in many empirical studies in the field of economics: Asane-Otoo (2016), Tezcur (2016), Bell and Jones (2015). Therefore we used this approach while checking whether RE specification is more justified than a simple pooled OLS model by Breusch-Pagan test. We also addressed the presence of autocorrelation and heteroscedasticity estimating a robust covariance matrix (HAC standard errors) following Arellano (1987). Such robust standard errors are valid when the number of units is larger than the number of periods, and this is the case in our sample (up to 27 units, and 8 periods). However, the length of time series is the main limitation in this research. We were limited to the accession date of EU-13 countries (2004), as well as by the CAP programming periods. The analysis has covered two of them almost entirely (2004-2006 and 2007-2013). We decided to exclude 2013 because we found too many outstanding observations in this year. The next programming period (2014-2020) is still ongoing, and for that reason should not be subjected to analysis since second pillar schemes may not be equally distributed among years in different countries and they may be concentrated in the second part of the period.

\section{Results and problem solution}

We have expressed, as mentioned, our initial data: the price gap (proxy for PCS), the productivity gap (volume effect) and different types of subsidies in monetary units in order to estimate the regression of the productivity measures and policy instruments on PCS. First of all, it is worth commenting on the descriptive statistics for the initial data, ie. price and volume effects $(\Delta \operatorname{Pr}$ and $\Delta \mathrm{INr}$ ), see Table 2 and 3. Considering year averages in 2004-2012, we can see that PCS occurred in some countries, such as Bulgaria, Greece, Spain, Portugal, Slovenia, regardless of farm size, while only in large and very large farms in the others, e.g. the Czech Republic, Denmark, Estonia, Nederland, Ireland, Lithuania, but in some cases the average price effect was positive in all SO classes, e.g. France, Germany, Italy. If we take into account EU-27 averages, we notice that only Vth and VIth SO classes are subject to PCS. Although in the other classes the price effect is positive, it does not deny the treadmill theory or long-term PCS.

The key observation from Tables 2 and 3 concerns the opposite signs in the volume and price effects in almost all cases. This confirms the hypothesis of flexible prices. Let us focus on EU-27 averages: In the Ist farm class, we observe a decline in factor productivity of $1.3 \%$, whereas there is the inflow of economic surplus through prices equal to $0.3 \%$. In the Ind class, the productivity loss of $0.9 \%$ is "compensated" with the improvement in prices calculated to $0.5 \%$ of output. In the IIIrd class, a negative volume effect of $-2.7 \%$ is partially countervailed by the price effect of $1.3 \%$. Further, in the IVth class, we counterpose $-0.7 \%$ of the volume effect versus $0.6 \%$ of the price effect. In large and very large farms, we observed productivity growth equal to $0.3 \%$ and $1.4 \%$ respectively, but this was drained out by the price effect of $-0.7 \%$ and $-1.4 \%$. 
Table 2. Descriptive statistics: decomposition of price and volume effect in $€$ related to output; year averages in 2004-2012 in the range of different economic size of farms (SO I - SO III) (source: own calculations using EU FADN dat and EAA Eurostat prices)

\begin{tabular}{|c|c|c|c|c|c|c|}
\hline \multirow[b]{2}{*}{ Country } & \multicolumn{2}{|c|}{ SO I } & \multicolumn{2}{|c|}{ SO II } & \multicolumn{2}{|c|}{ SO III } \\
\hline & $\begin{array}{l}\text { I-O volume } \\
\text { effect } \Delta I N r\end{array}$ & $\begin{array}{l}\text { I-O price } \\
\text { effect } \Delta P r\end{array}$ & $\begin{array}{l}\text { I-O volume } \\
\text { effect } \Delta I N r\end{array}$ & $\begin{array}{l}\text { I-O price } \\
\text { effect } \Delta P r\end{array}$ & $\begin{array}{l}\text { I-O volume } \\
\text { effect } \Delta I N r\end{array}$ & $\begin{array}{l}\text { I-O price } \\
\text { effect } \Delta P r\end{array}$ \\
\hline Austria & - & - & -0.026 & 0.020 & -0.017 & 0.015 \\
\hline Belgium & - & - & - & - & -0.013 & 0.005 \\
\hline Bulgaria & 0.006 & -0.016 & 0.014 & -0.017 & 0.003 & -0.009 \\
\hline Cyprus & -0.009 & 0.037 & 0.005 & -0.004 & -0.059 & 0.013 \\
\hline Czech Republic & - & - & -0.020 & 0.001 & -0.026 & 0.004 \\
\hline Denmark & - & - & -0.031 & 0.045 & 0.025 & 0.026 \\
\hline Estonia & - & - & -0.035 & 0.010 & -0.007 & 0.002 \\
\hline Finland & - & - & 0.031 & 0.009 & -0.058 & 0.001 \\
\hline France & - & - & - & - & -0.003 & 0.014 \\
\hline Greece & -0.015 & -0.003 & -0.025 & -0.004 & -0.019 & -0.006 \\
\hline Spain & -0.048 & -0.036 & -0.011 & -0.020 & -0.013 & -0.016 \\
\hline Netherlands & - & - & - & - & -0.056 & 0.011 \\
\hline Ireland & -0.058 & 0.015 & -0.028 & 0.016 & -0.023 & 0.018 \\
\hline Lithuania & -0.025 & 0.005 & -0.045 & 0.005 & -0.045 & -0.001 \\
\hline Luxembourg & - & - & - & - & -0.057 & 0.032 \\
\hline Latvia & 0.004 & -0.009 & -0.005 & -0.012 & 0.017 & -0.013 \\
\hline Malta & - & - & -0.031 & -0.008 & -0.019 & -0.005 \\
\hline Germany & - & - & - & - & -0.372 & 0.203 \\
\hline Poland & -0.031 & 0.016 & -0.022 & 0.011 & -0.014 & 0.004 \\
\hline Portugal & 0.062 & -0.032 & 0.039 & -0.031 & 0.037 & -0.035 \\
\hline Romania & -0.002 & 0.024 & 0.070 & 0.021 & 0.049 & 0.006 \\
\hline Slovakia & - & - & - & - & -0.012 & 0.008 \\
\hline Slovenia & -0.020 & 0.003 & -0.003 & -0.001 & -0.008 & -0.007 \\
\hline Sweden & - & - & -0.016 & 0.011 & -0.003 & 0.015 \\
\hline UK & - & - & -0.018 & 0.014 & -0.009 & 0.033 \\
\hline Hungary & -0.012 & 0.038 & -0.017 & 0.037 & -0.031 & 0.036 \\
\hline Italy & -0.019 & 0.002 & -0.008 & 0.004 & -0.009 & 0.003 \\
\hline UE-27 & -0.013 & 0.003 & -0.009 & 0.005 & -0.027 & 0.013 \\
\hline
\end{tabular}

Volume effect reflects changes in factor productivity, i.e. how the income would change as a result of changes in the volume of products and inputs if there were no price changes. (in output shares, e.g. -0.026 means that changes in output and input volumes, i.e. in productivity, caused a decrease in income equal to $-2.6 \%$ of revenues);

Price effect: reflects inflow/outflow of economic surplus through the changes of output and input prices (in output shares, e.g. 0.02 means that price changes caused a $2 \%$ increase in output value). 
Table 3. Descriptive statistics: decomposition of price and volume effect in $€$ related to output; year averages in 2004-2012 in the range of different economic size of farms (SO IV - SO VI) (source: own calculations using EU FADN data and EAA Eurostat prices)

\begin{tabular}{|c|c|c|c|c|c|c|}
\hline \multirow[b]{2}{*}{ Country } & \multicolumn{2}{|c|}{ SO IV } & \multicolumn{2}{|c|}{$\mathrm{SO} \mathrm{V}$} & \multicolumn{2}{|c|}{ SO VI } \\
\hline & $\begin{array}{l}\text { I-O volume } \\
\text { effect } \Delta I N r\end{array}$ & $\begin{array}{l}\text { I-O price } \\
\text { effect } \Delta P r\end{array}$ & $\begin{array}{l}\text { I-O volume } \\
\text { effect } \Delta I N r\end{array}$ & $\begin{array}{l}\text { I-O price } \\
\text { effect } \Delta P r\end{array}$ & $\begin{array}{l}\text { I-O volume } \\
\text { effect } \Delta I N r\end{array}$ & $\begin{array}{l}\text { I-O price } \\
\text { effect } \Delta P r\end{array}$ \\
\hline Austria & -0.010 & 0.011 & -0.001 & 0.007 & - & - \\
\hline Belgium & 0.011 & 0.004 & 0.088 & -0.092 & 0.199 & -0.196 \\
\hline Bulgaria & -0.064 & 0.005 & -0.030 & 0.006 & -0.008 & -0.004 \\
\hline Cyprus & -0.049 & 0.013 & -0.012 & -0.079 & - & - \\
\hline Czech Republic & -0.018 & -0.001 & -0.007 & -0.007 & 0.013 & -0.017 \\
\hline Denmark & 0.018 & 0.032 & 0.024 & 0.0001 & 0.020 & -0.007 \\
\hline Estonia & -0.019 & 0.009 & -0.001 & -0.004 & 0.002 & -0.017 \\
\hline Finland & -0.021 & 0.002 & 0.00002 & -0.012 & - & - \\
\hline France & -0.002 & 0.015 & -0.003 & 0.012 & -0.009 & 0.011 \\
\hline Greece & -0.017 & -0.004 & -0.035 & -0.007 & - & - \\
\hline Spain & -0.023 & -0.012 & -0.017 & -0.014 & -0.017 & -0.014 \\
\hline Netherlands & 0.008 & 0.006 & 0.008 & -0.001 & 0.012 & -0.006 \\
\hline Ireland & -0.014 & 0.003 & -0.003 & -0.005 & - & - \\
\hline Lithuania & -0.038 & 0.0003 & -0.010 & -0.006 & 0.009 & 0.001 \\
\hline Luxembourg & -0.034 & 0.031 & -0.014 & -0.002 & - & - \\
\hline Latvia & 0.018 & 0.007 & 0.004 & 0.018 & 0.025 & -0.018 \\
\hline Malta & 0.034 & -0.013 & -0.004 & -0.009 & - & - \\
\hline Germany & -0.003 & 0.007 & 0.006 & 0.001 & 0.006 & 0.004 \\
\hline Poland & -0.008 & 0.003 & -0.004 & 0.002 & 0.008 & 0.003 \\
\hline Portugal & 0.045 & -0.040 & 0.048 & -0.042 & - & - \\
\hline Romania & 0.091 & 0.015 & 0.059 & 0.005 & -0.025 & 0.029 \\
\hline Slovakia & -0.038 & -0.013 & -0.001 & 0.007 & -0.024 & 0.00004 \\
\hline Slovenia & -0.014 & -0.005 & 0.003 & -0.019 & - & - \\
\hline Sweden & -0.012 & 0.011 & -0.006 & 0.003 & 0.012 & -0.006 \\
\hline UK & -0.015 & 0.035 & -0.006 & 0.015 & 0.042 & -0.027 \\
\hline Hungary & -0.019 & 0.030 & -0.015 & 0.031 & -0.019 & 0.016 \\
\hline Italy & -0.008 & 0.003 & -0.002 & 0.006 & -0.003 & 0.006 \\
\hline UE-27 & -0.007 & 0.006 & 0.003 & -0.007 & 0.014 & -0.014 \\
\hline
\end{tabular}

Volume effect reflects changes in factor productivity, i.e. how income would change as a result of changes in the volume of products and inputs if there were no price changes. (in output shares, e.g. -0.01 means that changes in output and input volumes, i.e. in productivity, caused a decrease in income equal to $-1 \%$ of revenues);

Price effect: reflects inflow/outflow of economic surplus through the changes of output and input prices (in output shares, e.g. 0.011 means that changes in prices caused a $1.1 \%$ increase in output value). 
The message from this is that losses in productivity are only partially compensated by favourable changes in prices, while increases in productivity are consummated by PCS completely or with excess. Hence, bearing in mind the cyclical nature of agricultural production, it is likely that a positive price effect in the case of a productivity drop would be drained out with excess in the next part of the cycle by an unfavourable change in prices. In this context, the descriptive statistics in each SO class may be interpreted as being in line with Cochrane's treadmill theorem, who after all was considering the case of long-term productivity growth. Therefore, the opposite reaction of productivity versus price effect, which is asymmetric in downward and upward turns of the production cycle, plays the principal role in PCS theory. This has been confirmed by the estimated models, because in all SO classes $\Delta \mathrm{INr}$ turned to be significant and have the expected sign (the higher absolute productivity change, the higher absolute value of the price effect).

In the discussion of the estimated models (see Tables 4-6), we take into account the 3rd and 4th specifications of each model, since the DP variable inserted into the model in the 4th step was quite strongly collinear with the PG variable (VIF $\approx 4$ ) and so inflated the regression coefficients. Our findings confirm both hypotheses stated at the beginning, however the results differ in farms of different economic sizes (SO classes). Agricultural prices were flexible in the meaning that the agricultural price gap reacted as expected in the treadmill theory. The larger the farm, the stronger the positive effect of TFP changes on PCS. We also confirmed that decoupled subsidies enhance PCS, while the strength of the marginal effects increases along with the economic size of the farm. On the other hand, the payments for public goods (including environmental, LFA, rural development and set-aside subsidies) mitigate PCS but only in the smallest farms, i.e. Ist and IIIrd class, considering that the latter is usually the smallest one in Western European countries. Investment subsidies have a similar mitigating effect only in entities from the I SO class. Coming to more specific conclusions:

- The most important contribution to the treadmill theory provides that commodity prices are shaped globally, whereas the agricultural price gap is shaped locally (at the national level). This must happen due to the influence of monopsony power, since it is very unlikely that agricultural production swings are similar in different countries and simultaneously fitting global changes of prices.

- Only the cross-sectional part of PG (between-PG) has a mitigating effect on PCS, i.e. in countries where PG was greater, PCS was weaker (this concerns only the smallest farms as mentioned). When it comes to the time-variant part of PG share (within-PG), it positively affected PCS, and this effect strengthened when moving to higher SO classes. This raises the question of the more precise indication of the PG's recipients, and also shows that the latter are subject to rent-seeking and to some extent misused by the large and the largest farms.

- Interestingly, the marginal impact of productivity on price flexibility, regarding its absolute value, was only two times greater than the opposite effect of between-PG in very small farms (Ist SO) and almost 7-10 times stronger in the IIIrd SO. Hence, in the new member states, it is easier to compensate for market imperfection by increasing PG share. On the other hand, stimulating the PCS effects of within-PG was even 
two times greater than the effect of market drivers (productivity) in large and very large farms (Vth and VIth SO). The question is whether these entities are the right address for PGs payments.

- Considering DP, its effect on PCS is positive, and the coefficients of DP variable reach the level of $50 \%$ of the coefficients of the productivity variable. This means that single payments stimulate market imperfections and the market treadmill. This contests the effectiveness of DP as a predominant CAP scheme.

- The impact of productivity change on prices is more a cross-sectional effect than a time- variant factor (much lower parameters for the latter). However, it is a time-variant variable for the largest farms and the smallest ones, too, which may be a fairly expected conclusion. The largest farms well match the global changes in prices and are less subjected to monopsony impact. The smallest farms are semi-subsistent to some extent, and for that reason, they do not depend very much on the market structure.

Table 4. Random-effects (GLS) estimates for Ist and IInd SO class (robust HAC standard errors, dependent variable $\left|\Delta P r_{c, t}\right|$, all var. expressed in total output shares) (source: owna calcuations using EUFADN data and EAA Eurostat prices)

\begin{tabular}{|c|c|c|c|c|c|c|c|c|}
\hline & \multicolumn{4}{|c|}{ SO I } & \multicolumn{4}{|c|}{ SO II } \\
\hline & (1) & (2) & (3) & (4) & (1) & (2) & (3) & (4) \\
\hline const & $\begin{array}{c}0.060^{* * *} \\
(0.014)\end{array}$ & $\begin{array}{c}0.072^{* * *} \\
(0.017)\end{array}$ & $\begin{array}{c}0.070^{* * *} \\
(0.015)\end{array}$ & $\begin{array}{c}0.074^{* * *} \\
(0.021)\end{array}$ & $\begin{array}{c}0.040^{* * *} \\
(0.015)\end{array}$ & $\begin{array}{c}0.039^{* * *} \\
(0.015)\end{array}$ & $\begin{array}{l}0.040^{\star *} \\
(0.018)\end{array}$ & $\begin{array}{c}0.050^{* * *} \\
(0.016)\end{array}$ \\
\hline $\mid \begin{array}{l}\text { betw } \\
|\Delta I N r|\end{array}$ & $\begin{array}{c}0.046 \\
(0.110)\end{array}$ & $\begin{array}{c}0.005 \\
(0.110)\end{array}$ & $\begin{array}{c}0.024 \\
(0.109)\end{array}$ & $\begin{array}{c}0.002 \\
(0.116)\end{array}$ & $\begin{array}{c}0.343^{* * *} \\
(0.127)\end{array}$ & $\begin{array}{l}0.324^{\star *} \\
(0.129)\end{array}$ & $\begin{array}{l}0.326^{\star *} \\
(0.131)\end{array}$ & $\begin{array}{l}0.292^{* \star} \\
(0.131)\end{array}$ \\
\hline 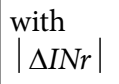 & $\begin{array}{l}0.089^{*} \\
(0.054)\end{array}$ & $\begin{array}{l}0.091^{\star} \\
(0.053)\end{array}$ & $\begin{array}{l}0.096^{*} \\
(0.055)\end{array}$ & $\begin{array}{c}0.100^{*} \\
(0.053)\end{array}$ & $\begin{array}{l}0.101^{\star} \\
(0.057)\end{array}$ & $\begin{array}{c}0.090 \\
(0.057)\end{array}$ & $\begin{array}{c}0.091 \\
(0.056)\end{array}$ & $\begin{array}{c}0.090 \\
(0.057)\end{array}$ \\
\hline betwPG & & $\begin{array}{c}-0.059^{\star *} \\
(0.029)\end{array}$ & $\begin{array}{c}-0.052^{\star} \\
(0.028)\end{array}$ & $\begin{array}{l}-0.046 \\
(0.079)\end{array}$ & & $\begin{array}{c}0.017 \\
(0.027)\end{array}$ & $\begin{array}{c}0.021 \\
(0.027)\end{array}$ & $\begin{array}{c}0.053 \\
(0.034)\end{array}$ \\
\hline withPG & & $\begin{array}{c}0.017 \\
(0.075)\end{array}$ & $\begin{array}{c}0.026 \\
(0.076)\end{array}$ & $\begin{array}{c}-0.004 \\
(0.075)\end{array}$ & & $\begin{array}{l}0.190^{\star *} \\
(0.083)\end{array}$ & $\begin{array}{l}0.186^{\star *} \\
(0.084)\end{array}$ & $\begin{array}{l}0.201^{* *} \\
(0.086)\end{array}$ \\
\hline betwIS & & & $\begin{array}{l}-0.023 \\
(0.159)\end{array}$ & $\begin{array}{c}-0.058 \\
(0.166)\end{array}$ & & & $\begin{array}{l}-0.060 \\
(0.116)\end{array}$ & $\begin{array}{l}-0.048 \\
(0.114)\end{array}$ \\
\hline withIS & & & $\begin{array}{c}-0.283^{\star} \\
(0.171)\end{array}$ & $\begin{array}{c}-0.304^{*} \\
(0.165)\end{array}$ & & & $\begin{array}{c}0.034 \\
(0.139)\end{array}$ & $\begin{array}{c}0.078 \\
(0.141)\end{array}$ \\
\hline betwDP & & & & $\begin{array}{l}-0.015 \\
(0.100)\end{array}$ & & & & $\begin{array}{l}-0.068 \\
(0.043)\end{array}$ \\
\hline withDP & & & & $\begin{array}{l}0.150^{\star *} \\
(0.074)\end{array}$ & & & & $\begin{array}{l}-0.084 \\
(0.070)\end{array}$ \\
\hline $\mathrm{n}$ & 97 & 97 & 97 & 97 & 161 & 161 & 161 & 161 \\
\hline $\ln L$ & 155 & 156 & 158 & 160 & 235 & 237 & 237 & 240 \\
\hline
\end{tabular}

Notes: Standard errors in parentheses; ${ }^{*}$ indicates significance at the 10 percent level, ${ }^{\star *}$ indicates significance at the 5 percent level, ${ }^{* *}$ indicates significance at the 1 percent level. 
Table 5. Random-effects (GLS) estimates for III SO and pooled OLS estimates for SO IV (robust HAC standard errors, dependent variable $\left|\Delta P r_{c, t}\right|$, all var. expressed in total output shares) (source: owna calcuations using EUFADN data and EAA Eurostat prices)

\begin{tabular}{|c|c|c|c|c|c|c|c|c|}
\hline & \multicolumn{4}{|c|}{ SO III } & \multicolumn{4}{|c|}{ SO IV } \\
\hline & (1) & (2) & (3) & (4) & (1) & (2) & (3) & (4) \\
\hline const & $\begin{array}{c}0.040^{* * *} \\
(0.011)\end{array}$ & $\begin{array}{c}0.044^{* * *} \\
(0.012)\end{array}$ & $\begin{array}{c}0.041^{\star * *} \\
(0.011)\end{array}$ & $\begin{array}{c}0.041^{* * *} \\
(0.013)\end{array}$ & $\begin{array}{c}0.035^{\star * *} \\
(0.006)\end{array}$ & $\begin{array}{c}0.034^{* * *} \\
(0.004)\end{array}$ & $\begin{array}{c}0.034^{* * *} \\
(0.005)\end{array}$ & $\begin{array}{l}0.021^{* *} \\
(0.008)\end{array}$ \\
\hline $\begin{array}{l}\text { betw } \\
|\Delta I N r|\end{array}$ & $\begin{array}{c}0.408^{\star * *} \\
(0.074)\end{array}$ & $\begin{array}{c}0.417^{\star * *} \\
(0.079)\end{array}$ & $\begin{array}{c}0.421^{\star * *} \\
(0.079)\end{array}$ & $\begin{array}{c}0.425^{\star * *} \\
(0.083)\end{array}$ & $\begin{array}{c}0.518^{\star * *} \\
(0.089)\end{array}$ & $\begin{array}{c}0.518^{\star * *} \\
(0.086)\end{array}$ & $\begin{array}{c}0.481^{\star * *} \\
(0.077)\end{array}$ & $\begin{array}{c}0.491^{\star * *} \\
(0.086)\end{array}$ \\
\hline $\begin{array}{l}\text { with } \\
|\Delta I N r|\end{array}$ & $\begin{array}{c}0.444^{* * *} \\
(0.020)\end{array}$ & $\begin{array}{c}0.443^{\star * *} \\
(0.020)\end{array}$ & $\begin{array}{c}0.442^{\star * *} \\
(0.019)\end{array}$ & $\begin{array}{c}0.441^{\star * *} \\
(0.020)\end{array}$ & $\begin{array}{l}0.222^{\star *} \\
(0.073)\end{array}$ & $\begin{array}{c}0.201^{\star *} \\
(0.070)\end{array}$ & $\begin{array}{c}0.197^{\star *} \\
(0.071)\end{array}$ & $\begin{array}{l}0.192^{\star *} \\
(0.067)\end{array}$ \\
\hline betwPG & & $\begin{array}{c}-0.043^{\star} \\
(0.024)\end{array}$ & $\begin{array}{c}-0.061^{\star * *} \\
(0.016)\end{array}$ & $\begin{array}{c}-0.053^{*} \\
(0.029)\end{array}$ & & $\begin{array}{c}0.004 \\
(0.064)\end{array}$ & $\begin{array}{l}-0.010 \\
(0.057)\end{array}$ & $\begin{array}{l}-0.044 \\
(0.045)\end{array}$ \\
\hline withPG & & $\begin{array}{c}0.270^{\star * *} \\
(0.103)\end{array}$ & $\begin{array}{l}0.226^{\star *} \\
(0.109)\end{array}$ & $\begin{array}{c}0.175 \\
(0.157)\end{array}$ & & $\begin{array}{c}0.365^{\star \star} \\
(0.136)\end{array}$ & $\begin{array}{c}0.292 \\
(0.157)\end{array}$ & $\begin{array}{c}0.134 \\
(0.135)\end{array}$ \\
\hline betwIS & & & $\begin{array}{c}0.137 \\
(0.096)\end{array}$ & $\begin{array}{c}0.142 \\
(0.132)\end{array}$ & & & $\begin{array}{c}0.184 \\
(0.110)\end{array}$ & $\begin{array}{c}0.209^{\star} \\
(0.099)\end{array}$ \\
\hline withIS & & & $\begin{array}{c}0.200 \\
(0.172)\end{array}$ & $\begin{array}{c}0.164 \\
(0.167)\end{array}$ & & & $\begin{array}{c}0.274^{\star} \\
(0.123)\end{array}$ & $\begin{array}{c}0.235^{\star} \\
(0.121)\end{array}$ \\
\hline betwDP & & & & $\begin{array}{l}-0.004 \\
(0.039)\end{array}$ & & & & $\begin{array}{c}0.109^{\star} \\
(0.050)\end{array}$ \\
\hline withDP & & & & $\begin{array}{c}0.085 \\
(0.124)\end{array}$ & & & & $\begin{array}{c}0.247^{* *} \\
(0.089)\end{array}$ \\
\hline $\mathrm{n}$ & 210 & 210 & 210 & 210 & 210 & 210 & 210 & 210 \\
\hline $\ln \mathrm{L}$ & 306 & 309 & 311 & 312 & 305 & 306 & 308 & 312 \\
\hline Adj. $\mathrm{R}^{2}$ & - & - & - & - & 0.130 & 0.133 & 0.142 & 0.165 \\
\hline
\end{tabular}

Notes: Standard errors in parentheses; ${ }^{*}$ indicates significance at the 10 percent level, ${ }^{\star \star}$ indicates significance at the 5 percent level, ${ }^{* *}$ indicates significance at the 1 percent level.

It is quite difficult to compare these results with similar studies, because this kind of approach has rarely been undertaken. Although there are many studies testing the occurrence of PCS (cited above), in which results differ regarding the choice of commodities, we are focusing on the market and policy influence on PCS. Moreover, this may be discussed only indirectly based on theoretical assumptions on the relationship between productivity and agricultural income (c.f. Figure 2 ). If we treat capital productivity growth as an inhibitor of PCS, we should discuss the many recent empirical studies on the effects of CAP subsidies on productivity. One of the most recent empirical works is presented by Mary (2013), who investigated the effect of CAP Pillar I and Pillar II subsidies on French crop farms using a panel data approach. The results show that set-aside, Less Favoured Areas (LFA) payments and livestock payments have a negative effect on productivity. Rizov et al. (2013) who also looked at the impact of CAP subsidies on agricultural productivity, using farm level EU FADN data confirmed the negative influence, which improves after decoupling. Latruffe, Bravo-Ureta, Moreira, Desjeux, and Dupraz (2011) investigated the effect of subsidies on technical efficiency and found that farms with higher subsidy rates had lower technical efficiency. 
Table 6. Pooled OLS estimates for Vth and VIth SO class (robust HAC standard errors, dependent variable $\left|\Delta P r_{c, t}\right|$, all var. expressed in total output shares) (source: own calcuations using EUFADN data and EAA Eurostat prices)

\begin{tabular}{|c|c|c|c|c|c|c|c|c|}
\hline & \multicolumn{4}{|c|}{$\mathrm{SO} \mathrm{V}$} & \multicolumn{4}{|c|}{ SO VI } \\
\hline & (1) & (2) & (3) & (4) & (1) & (2) & (3) & (4) \\
\hline const & $\begin{array}{l}0.022^{\star *} \\
(0.009)\end{array}$ & $\begin{array}{c}0.018^{\star} \\
(0.008)\end{array}$ & $\begin{array}{c}0.017^{\star} \\
(0.008)\end{array}$ & $\begin{array}{l}-0.006 \\
(0.010)\end{array}$ & $\begin{array}{c}0.017 \\
(0.021)\end{array}$ & $\begin{array}{c}0.013 \\
(0.021)\end{array}$ & $\begin{array}{c}0.013 \\
(0.020)\end{array}$ & $\begin{array}{c}0.008 \\
(0.021)\end{array}$ \\
\hline \begin{tabular}{|l|} 
betw \\
$|\Delta I N r|$
\end{tabular} & $\begin{array}{c}0.745^{* * *} \\
(0.164)\end{array}$ & $\begin{array}{c}0.753^{* * *} \\
(0.164)\end{array}$ & $\begin{array}{c}0.725^{* * *} \\
(0.190)\end{array}$ & $\begin{array}{c}0.713^{* * *} \\
(0.186)\end{array}$ & $\begin{array}{c}0.626 \\
(0.348)\end{array}$ & $\begin{array}{c}0.636 \\
(0.359)\end{array}$ & $\begin{array}{c}0.631 \\
(0.372)\end{array}$ & $\begin{array}{c}0.636 \\
(0.379)\end{array}$ \\
\hline \begin{tabular}{|l|} 
with \\
$|\Delta I N r|$
\end{tabular} & $\begin{array}{c}0.422^{* * *} \\
(0.119)\end{array}$ & $\begin{array}{l}0.393^{\star *} \\
(0.118)\end{array}$ & $\begin{array}{c}0.371^{* * *} \\
(0.093)\end{array}$ & $\begin{array}{c}0.378^{\star * *} \\
(0.088)\end{array}$ & $\begin{array}{l}0.407^{*} \\
(0.198)\end{array}$ & $\begin{array}{c}0.415^{\star} \\
(0.187)\end{array}$ & $\begin{array}{l}0.412^{\star} \\
(0.187)\end{array}$ & $\begin{array}{l}0.407^{\star *} \\
(0.170)\end{array}$ \\
\hline betwPG & & $\begin{array}{c}0.054 \\
(0.072)\end{array}$ & $\begin{array}{c}0.017 \\
(0.068)\end{array}$ & $\begin{array}{c}-0.088^{\star} \\
(0.045)\end{array}$ & & $\begin{array}{c}0.204 \\
(0.322)\end{array}$ & $\begin{array}{c}0.150 \\
(0.407)\end{array}$ & $\begin{array}{c}0.061 \\
(0.480)\end{array}$ \\
\hline withPG & & $\begin{array}{c}0.478^{* * *} \\
(0.109)\end{array}$ & $\begin{array}{c}0.391^{\star \star \star} \\
(0.107)\end{array}$ & $\begin{array}{c}0.226^{\star} \\
(0.124)\end{array}$ & & $\begin{array}{c}1.526^{* * *} \\
(0.211)\end{array}$ & $\begin{array}{c}1.423^{* * *} \\
(0.181)\end{array}$ & $\begin{array}{c}0.952^{* * *} \\
(0.221)\end{array}$ \\
\hline betwIS & & & $\begin{array}{c}0.240 \\
(0.204)\end{array}$ & $\begin{array}{c}0.300 \\
(0.174)\end{array}$ & & & $\begin{array}{c}0.187 \\
(0.975)\end{array}$ & $\begin{array}{c}0.285 \\
(1.045)\end{array}$ \\
\hline withIS & & & $\begin{array}{c}0.903^{\star * *} \\
(0.121)\end{array}$ & $\begin{array}{c}0.755^{\star * *} \\
(0.164)\end{array}$ & & & $\begin{array}{c}0.318 \\
(0.207)\end{array}$ & $\begin{array}{c}0.021 \\
(0.231)\end{array}$ \\
\hline betwDP & & & & $\begin{array}{c}0.271^{\star *} \\
(0.089)\end{array}$ & & & & $\begin{array}{c}0.074 \\
(0.185)\end{array}$ \\
\hline withDP & & & & $\begin{array}{c}0.345^{\star *} \\
(0.128)\end{array}$ & & & & $\begin{array}{l}0.673^{\star *} \\
(0.212)\end{array}$ \\
\hline $\mathrm{n}$ & 210 & 210 & 210 & 210 & 136 & 136 & 136 & 136 \\
\hline $\ln \mathrm{L}$ & 0.244 & 0.252 & 0.308 & 0.343 & 0.324 & 0.356 & 0.348 & 0.366 \\
\hline Adj. $\mathrm{R}^{2}$ & 300 & 302 & 311 & 317 & 203 & 208 & 208 & 211 \\
\hline
\end{tabular}

Notes: Standard errors in parentheses; ${ }^{*}$ indicates significance at the 10 percent level, ${ }^{\star *}$ indicates significance at the 5 percent level, ${ }^{* * *}$ indicates significance at the 1 percent level.

On the other hand, Minviel and Latruffe (2014) performed a meta-analysis of 195 results of studies on the effect of subsidies and came to the conclusion that aggregating all subsidies received by farmers to one value of a support increases the probability of a negative effect on farms' technical efficiency, but if one investigates different subsidy groups separately, investment subsidy positively impacts on technical efficiency. This line of reasoning has been supported by the above cited Dudu and Kristkowa (2017) who advocated that human capital, physical capital and agro-environmental subsidies have a positive and significant contribution on labour, capital and land productivity respectively. These findings indirectly confirm the author's conclusion on the mitigating impact of PG subsidies on PCS. Although agroenvironmental subsidies are assumed to be counterproductive and to have a negative impact on land use, it is likely that they force implementation of more inputs to the residual parts of the land, ultimately improving land productivity (Dudu \& Kristkowa, 2017) and elasticity of supply. In the case of the smallest farms (Ist or IIIrd SO class), payments for public goods provide an opportunity to capitalise land rent from the less productive plots and an incentive to be a more market-oriented player than others. 


\section{Conclusions}

Agricultural policymakers should focus on the statement that commodity prices are shaped globally, but the agricultural price gap is shaped locally (at the national level). The effectiveness of CAP may be substantially lowered by the counterproductive side effects of direct payments since they are very likely to enhance PCS (as well as the market treadmill). We postulate not a growth of the PG share but rather addressing PG payments more precisely to the smallest farms. In large and very large entities, an increase of such payments result in the faster drainage of surpluses through the price gap. The results give interesting insights into the treadmill mechanism, showing that public goods provision may be to some extent a remedy for market imperfections, such as flexible prices related to a monopsony power. EU policymakers should reconsider an evolution towards a kind of dual model of support featured by subsidies enhancing technical progress (mainly for medium and large farms) on the one hand and PG payments on the other (for the smallest farms). Both types of support might weaken PCS and make it easier to cope with the treadmill. However, we do not consider a return to coupled payments, but rather we raise the question of linking the single payment to investment spending which might improve the technical efficiency of farms. In the present form of support, even if governments intervened to maintain incomes, the benefits from developments in agricultural technology accrue in large part to intermediaries, processors and consumers.

\section{Acknowledgements}

This article is founded by the National Science Centre in Poland (grant no. 2016/21/B/ HS4/00653)

\section{References}

Arellano, M. (1987). Computing robust standard errors for within group estimators. Oxford Bulletin of Economics and Statistics, 49, 431-434.

Asane-Otoo, E. (2016). Competition policies and environmental quality: an empirical analysis of the electricity sector in OECD countries. Energy Policy, 95, 121-223.

https://doi.org/10.1016/j.enpol.2016.05.001

Bell, A., \& Jones, K. (2015). Explaining fixed effects: random effects modeling of time-series crosssectional and panel data. Political Science Research and Methods, 3(1), 133-153. https://doi.org/10.1017/psrm.2014.7

Boháčková, I. (2014). Some notes to income disparity problems of agriculture. Agris on-line Papers in Economics and Informatics, 5(4), 2-11.

Barath, L., \& Ferto, I. (2017). Productivity and convergence in European agriculture. Journal of Agricultural Economics, 68(1), 228-248. https://doi.org/10.1111/1477-9552.12157

Campiche, J. L., Bryan, H. L., Richardson, J. W., \& Outlaw, J. L. (2006). Investigation of the cost-price squeeze for individual agricultural commodities. Paper prepared at Western Agricultural Economics Association Annual Meetings. Anchorage, Alaska. Retrieved 13 December 2018 from http://ageconsearch.umn.edu/bitstream/35357/1/sp06ca01.pdf 
Chen, Z., Lent, R. (1992). Supply analysis in an Oligopsony model. American Journal of Agricultural Economics, 74(4), 973-979. https://doi.org/10.2307/1243195

Chen, Z., Huffman, W. E., \& Rozelle, S. (2011). Inverse relationship between productivity and farm size: the case of China. Contemporary Economic Policy, 29(4): 580-592. https://doi.org/10.1111/j.1465-7287.2010.00236.x

Chodakowska, E., \& Nazarko, J. (2017). Environmental DEA method for assessing productivity of European countries. Technological and Economic Development of Economy, 23(4), 589-607. https://doi.org/10.3846/20294913.2016.1272069

Ciaian, P., Kancs, d'A., \& Espinosa, M. (2017). The impact of the 2013 CAP reform on the decoupled payments' capitalisation into land values. Journal of Agricultural Economics, 69(2), 306-337. https://doi.org/10.1111/1477-9552.12253

Cochrane, W. (1958). Farm prices: Myth and reality. Minneapolis: University of Minnesota Press.

Coelli, T. J., Prasada Rao, D. S., Donnell, Ch. J., \& Battese, G. E. (2005). An introduction to efficiency and productivity analysis. Armidale: Springer.

Czajanow, A. (1931). The socio-economic nature of peasant farm economy. In P. A. Sorokin, C. C. Zimmerman, C. J. Galpin (Eds). A systematic source book in rural sociology, (Vol. 2). Minneapolis.

Czajanow, A. (1966). The theory of peasant economy. New York: The University of Wisconsin Press.

Czajanow, A. (1991). The theory of peasant co-operatives. London: I. B. Tauris.

Czyzewski, B., Guth, M., \& Matuszczak, A. (2018a). The impact of the CAP green programmes on farm productivity and its social contribution. Problemy Ekorozwoju - Problems of Sustainable Development, 13(1), 173-183.

Czyżewski, B., \& Majchrzak, A. (2018). Market versus agriculture in Poland-macroeconomic relations of incomes, prices and productivity in terms of the sustainable development paradigm. Technological and Economic Development of Economy, 24(2), 318-334. https://doi.org/10.3846/20294913.2016.1212743

Czyżewski, B., Matuszczak, A., \& Muntean, A. (2018b). Influence of agricultural policy on the environmental sustainability of European farming, Journal of Environmental Protection and Ecology, 19(1), 426-434.

Dudu, H., \& Krsitkova, Z. S. (2017). Impact of CAP Pillar II Payments on Agricultural Productivity. JRC Technical Report. Luxembourg: Publications Office of the European Union. https://doi.org/10.2760/802100

Dürr, J. 2016. The political economy of agriculture for development today: the "small versus large" scale debate revisited. Agricultural Economics, 47(6), 671-681. https://doi.org/10.1111/agec.12264

EU Farm Accountancy Data Network [EUFADN]. (2017). Retrieved 10 October 2017 from http://ec.europa.eu/agriculture/rica/database/database_en.cfm

Freebairn, J. (2017). Effects of supermarket monopsony pricing on agriculture. Paper presented at 61st AARES Annual Conference, 7-10 February, University of Melbourne Brisbane, Australia.

Gabre-Madhin, E., Barrett, Ch. B., \& Dorosh, P. (2002). Technological Change and Price Effects in Agriculture: Conceptual and Comparative Perspectives, (pp. 8-10). Washington, DC: International Food Policy Research Institute (IFPRI).

Galbraith, J. K. (1993). American capitalism, the concept of countervailing power. Rotledge: Taylor \& Francis Group.

Gardner, B. L. (1992). Changing economic perspectives on the farm problem. Journal of Economic Literature, 30(1), 62-101.

Hayami, Y., \& Herdt, R. W. (1977). Market price effects of technological change on income distribution in semi subsistence agriculture. American Journal of Agricultural Economics, 59(2), 245-256.

https://doi.org/10.2307/1240014 
Heberton Evans Jr., G. (1967). The law of demand - the roles of Gregory King and Charles Davenant. The Quarterly Journal of Economics, 81(3), 483-492. https://doi.org/10.2307/1884813

Heinrichsmayer, W., \& Witzke, H. P. (1991). Agrarpolitik Band 1: Agrarökonomische grundlagen. Stuttgart: UTB

Hertel, T. W., \& Tsigas, M. E. (1997). Structure of GTAP. In T. W. Hertel (Ed.), Global Trade Analysis. Modeling and Applications. Cambridge: Cambridge University Press.

Hertel, T. W., Tsigas, M. E., \& Narayanan, B. G. (2008). Primary factor shares. GTAP 7 Data Base Documentation, 12.A. Retrieved from https://www.gtap.agecon.purdue.edu/resources/download/ 4182.Pdf

Johnson, D. G. (2000). Reducing the urban-rural income disparity (Paper No. 00-07). Chicago IL: University of Chicago.

Kiryluk-Dryjska, E., \& Beba, P. (2018). Region-specific budgeting of rural development funds - an application study. Land Use Policy, 77, 126-134. https://doi.org/10.1016/j.landusepol.2018.05.029

Latruffe, L., Bravo-Ureta, B., Moreira, V., Desjeux, Y., \& Dupraz, P. (2011). Productivity and subsidies in European Union countries: An analysis for dairy farms using input distance frontiers. Paper presented at EAAE 2011 Congress Change and Uncertainty. Zürich, Switzerland.

Levins, R. A. \& Cochrane, W. W. (1996). The treadmill revisited. Land Economics, 72(4), 550-553. https://doi.org/10.2307/3146915

Majiwa, E., Leeb, B. L. \& Wilsonb, C. (2018). Increasing agricultural productivity while reducing greenhouse gas emissions in sub-Saharan Africa: myth or reality? Agricultural Economics, 49, 183-192. https://doi.org/10.1111/agec.12407

Mary, S. (2013). Assessing the impacts of pillar 1 and 2 subsidies on TFP in French crop farms. Journal of Agricultural Economics, 64(1): 133-144. https://doi.org/10.1111/j.1477-9552.2012.00365.x

Milczarek-Andrzejewska, D., Zawalińska, K., \& Czarnecki, A. (2018). Land-use conflicts and the common agricultural policy: evidence from Poland. Land Use Policy, 73, 423-433.

https://doi.org/10.1016/j.landusepol.2018.02.016

Millard, S., \& O'Grady, T. (2012). What do sticky and flexible prices tell us? (Working Paper No. 457). London: Publications Group, Bank of England, 1-28.

Minviel, J. J., \& Latruffe, L. (2014). Meta-regression analysis of the impact of agricultural subsidies on farm technical efficiency. In EAAE 2014 Congress Agri-Food and Rural Innovations for Healthier Societies' (Vol. 26). August.

Moss, C. B. (1992). The cost-price squeeze in agriculture: An application of cointegration. Review of Agricultural Economics, 14(2), 205-13. https://doi.org/10.2307/1349500

Mundlak, Y. (1978). On pooling time series and cross section data. Econometrica, 46(1), 69-85. https://doi.org/10.2307/1913646

The Organisation for Economic Co-operation and Development [OECD]. (2000). A Matrix Approach to Evaluating Policy: Preliminary Findings from PEM Pilot Studies of Crop Policy In the EU, the US, Canada and Mexico. OECD Directorate for Food, Agriculture and Fisheries Trade Directorate, Paris.

The Organisation for Economic Co-operation and Development [OECD]. (2017). Retrieved 12 October 2017 from https://data.oecd.org/gdp/gdp-long-term-forecast.htm\#indicator-chart

Pawlak, K. (2018). Agricultural productivity, trade and food self-sufficiency: Evidence from Poland. The EE And The US. In Proceedings of the 27th International Scientific Conference 'Agrarian Perspectives XXVII. Food Safety - Food Security' (pp. 215-235). 20 September 2013, Prague, Czech Republic.

Rizov, M., Pokrivcak, J., \& Ciaian, P. (2013). CAP subsidies and productivity of the EU farms. Journal of Agricultural Economics, 64(3), 537-557. https://doi.org/10.1111/1477-9552.12030 
Schunck, R. (2013). Within and between estimates in random-effects models: Advantages and drawbacks of correlated random effects and hybrid models. The Stata Journal, 13(1), 65-76. https://doi.org/10.1177/1536867X1301300105

Shields, D. A. (2010). The farm price-cost squeeze and U.S. Farm policy. CRS Report for Congress: Congressional Research Service. Retrieved 13 December 2018 from http://nationalaglawcenter.org/ wp-content/uploads/assets/crs/R40761.pdf .

Staniszewski, J. (2018) Attempting to measure sustainable intensification of agriculture in countries of the European Union. Journal of Environmental Protection and Ecology 19(2), 949-957.

Tezcur, G. (2016). Ordinary people, extraordinary risks: participation in an ethnic rebellion. American Political Science Review, 110(2), 247-264. https://doi.org/10.1017/S0003055416000150

Tomek, W. G., \& Robinson, K. L. (1981). Agricultural product prices. Ithaca, London: Cornell University Press.

Tweeten, L., \& Zulauf, C. (2008). Farm price and income policy: lessons from history. Agribusiness, 24(2), 145-160. https://doi.org/10.1002/agr.20153

Vergopoulos, K. (1978). Capitalism and peasant productivity. The Journal of Peasant Studies, 5(4), 446465. https://doi.org/10.1080/03066157808438057

Wooldrige, J. (2013). Introductory econometrics: A modern approach. South-Western: Cengage Learning. 